\title{
Isolation, Biochemical and Molecular Characterization of Endophytic Bacteria from Tomato (Lycopersicon esculentum Mill.)
}

\author{
B. Sai Sushma*, B. Vidya Sagar, S. Triveni and G. Uma Devi \\ Department of Plant Pathology, Professor Jayashankar Telangana State Agricultural \\ University (PJTSAU), Rajendranagar, Hyderabad, India \\ *Corresponding author
}

\section{A B S T R A C T}

\begin{tabular}{|l|} 
Key w or d s \\
Endophytic \\
bacteria, Bacillus \\
sp., 16S rRNA \\
sequencing
\end{tabular}

Introduction

Tomato (Lycopersicon esculentum Mill.) is one of the most important vegetable crops in India. It is a good source of vitamins, minerals, organic acids, essential amino acids and dietary fibers. The main tomato developing nations are the USA, a few European nations, China and Japan. In India, tomato is cultivated in an area of about 193.7 mha in the states Andhra Pradesh (27. 93mt) followed by Madhya Pradesh (24.60mt), Karnataka (18.37 mt), Gujarat (14.25mt), Odisha (13.12mt), West Bengal (12.65 mt) and Telangana $(8.91 \mathrm{mt})$. In Telangana, tomato is cultivated in an area of 0.7 mha with an annual production of 19.37 million tons. The productivity is $28.1 \mathrm{MT} / \mathrm{ha}$ (INDIASTAT, 2017-18). The leading tomato growing districts in Telangana are Ranga Reddy, Medak, Khammam, Adilabad and Mahaboobnagar

The productivity of tomato is low due to several abiotic and biotic stresses. The pervasiveness of high humidity and warm temperature amid the growing season makes the crop vulnerable to infection by various biotic factors such as fungi, bacteria, virus and nematodes bringing about noteworthy 
yield misfortunes. Fungicide application is the most widely used approach for the management of the disease. However, use of fungicides poses serious problems such as development of resistance in the pathogen, environmental pollution, accumulation of fungicide residues and reduction of beneficial microbe population. Hence, alternative techniques like use of plant extracts and biocontrol agents that cause little or no loss to the environment are to be taken into consideration. But most of the research focused on the use of bacteria as biocontrol agents has involved the use of rhizospheric bacteria and not much attention was given to endophytic bacteria.

Endophytic bacteria are those bacteria that colonize the inner tissues of healthy plants without causing symptoms of disease or detrimental effect on their host. Endophytic bacteria have been isolated from many different plants including trees, fodder crops, vegetables, fruits, cereal grains and other crops (O'Sullivan et al., 1992). Endophytic bacteria are prokaryotes that colonize internal tissues of healthy plants without causing any disease symptoms. After they gain entry into the plant, they may be either localized at the point of entry or spread through the plant (Hallman et al., 1997). Endophytes synthesize bioactive compounds like alkaloids, steroids, terpenoids, peptides, polyketones, flavonoids, quinols and phenols that stimulate plant growth and increase resistance to the plant pathogens (Rosenblueth et al., 2006).

Use of endophytic bacteria can be considered as anew source of biocontrol agents in the plant disease management (Backman et al., 2008), as they share the same ecological niche as that of plant pathogens, which makes them suitable for biocontrol (Ryan et al., 2008).

The aim of present work was to isolate new bacterial endophytes, characterizing them biochemically and for plant growth promotion.

\section{Materials and Methods}

\section{Isolation of endophytic bacteria}

Sample collection and isolation of endophytic bacteria

Healthy tomato plant samples were collected and separated into root, shoot and leaf portions. The plant portions were surface sterilized by sequential immersion in 70 per cent alcohol for 30 seconds and 5 per cent sodium hypochlorite for 15 minutes followed by three washes in sterile distilled water and ground using mortar and pestle (Feng et al., 2013).

The ground sample was then serially diluted and spread on the Tryptic Soy Agar (TSA) plates. The plates were then incubated at $28 \pm$ $2^{\circ} \mathrm{C}$ in the BOD incubator for 2-3 days (Padder et al., 2017).

An aliquot of $0.1 \mathrm{ml}$ was taken from the final rinse and plated on TSA to check the efficacy of surface sterilization. A total of 24 isolates obtained in this manner were maintained on TSA slants and stored at $4^{\circ} \mathrm{C}$.

\section{Biochemical characterization of endophytic bacteria}

\section{HCN production}

The ability of the bacterial isolates to produce HCN was estimated by growing the bacterial isolates on TSA amended with $4.4 \mathrm{~g} / \mathrm{L}$ of glycine (Bakker et al., 1987). The indication for HCN production was recorded as a change in the colour of filter paper to brown and the isolates were scored based on intensity of the colour of filter paper. 


\section{Siderophore production}

Chrome azurol S (CAS) assay was used to detect siderophores produced by endophytic bacteria. Siderophore production was tested on petri dishes contained CAS - agar. Pure isolates of endophytic bacteria were spotted on CAS agar plates and incubated at $28 \pm 2{ }^{\circ} \mathrm{C}$ for 5 days in the dark.

The colonies with orange zones were considered as positive for siderophore production. The control plates of CAS - agar were incubated under the same conditions as described above and no color change in the CAS - blue agar was observed, after incubation period of 3-5days.

\section{Ammonia production}

Ammonia production by the endophytic bacterial isolates was tested according to Cappuccino et al., 1992. Based on the intensity of colour, the isolates were divided into four groups i.e.,,,,++++++++++ .

\section{IAA production}

Indole acetic acid production test was carried out by using the following method (Glickmann et al., 1995). The bacterial cultures were grown in TS Broth amended with $0.1 \%$ DL - tryptophan and incubatedat $30 \pm 2^{\circ} \mathrm{Cat} 180 \mathrm{RPMinthedarkfor} 5 \mathrm{da}$ ys in a shaker incubator. Two $\mathrm{ml}$ supernatant was taken and two drops of orthophosphoric acid and $4 \mathrm{ml}$ of Salkowski reagent were added to the supernatant. The tubes were incubated at room temperature for 30 minutes. Based on the colour intensity, the isolated bacterial endophytes were divided into four groups i.e., - , +, ++, +++ and the scores assigned were $0,1,2$ and 3respectively. The quantitative analysis of IAA was performed by measuring the $\mathrm{OD}$ at $530 \mathrm{~nm}$ in a spectrophotometer.

\section{Molecular characterization of endophytic bacteria}

The total genomic DNA of each isolate was extracted by following standard method (Chun et al., 1995). The PCR amplification of the 16S rRNA gene of the selected strains was done by using forward and reverse primers including, 27F5'- AGAGTTTGATCCTGG CTCAG-3 ${ }^{\prime}$ and 1492R 5'-CGGTTACCTTG TTACGACTT- $3^{\prime}$ primers. The reaction mixture was incubated in a thermal cycler (Eppendorf, Germany) and the conditions for PCR amplification were $94^{\circ} \mathrm{C}$ for 3 min for initial denaturation, followed by 35 cycles of $94^{\circ} \mathrm{C}$ for $30 \mathrm{sec}, 50^{\circ} \mathrm{C}$ for $30 \mathrm{sec}, 72^{\circ} \mathrm{C}$ for $90 / 60 \mathrm{sec}$ and final extension at $72^{\circ} \mathrm{C}$ for 7 min and the products were sequenced. The BLAST search program (http://www.ncbi.nlm.nih.gov/ BLAST/ Blast.cgi) was used to compare the sequence homology of nucleotides.

\section{Results and Discussion}

\section{Isolation of endophytic bacteria}

Twenty four isolates of endophytic bacteria were isolated from tomato root, stem and leaf portions of tomato plants on the TSA medium. Colonies with different morphological characters on TSA were further characterized. The number of isolates and the source of their isolation are mentioned in Table 1.

Inuwa et al., 2017isolated sixteen endophytic bacteria were isolated from roots and leaves of lemon grass wherein the roots harbored higher populations of endophytic bacteria. Similarly, abundance of Bacillus in tomato plants was reported when eight endophytic bacteria from tomato plants out of which two were found to be Gram negative and the remaining six isolates were Gram positive (Amaresan et al., 2012). 


\section{Morphological characterization}

Colony morphology is commonly used to distinguish bacterial genotypes on plates (Saxer et al., 2010). All the 24 isolates of endophytic bacteria were selected based on the different morphological characteristics. The morphological characters of all the isolates are shown in the Table 2.

\section{Gram's staining}

Out of 24 isolates tested, 15 isolates were gram positive bacilli, 5 were gram positive cocci, 3 were gram negative rod and only 1 was gram negative cocci. This indicated that majority $(62.5 \%)$ of the bacteria observed in this study belong to gram positive bacilli followed by $20.5 \%$ of gram positive cocci. Gram negative cocci seemed to be most uncommon accounting to only $4.16 \%$ of the total isolates.

Biochemical characterization of endophytic bacterial isolates

\section{Ammonia production}

Another important feature of endophytic bacteria is the production of ammonia, which indirectly affects the growth in plants. Certain endophytic bacteria can provide nitrogen to the plants through biological nitrogen fixation, which is an important source of nitrogen input in Agriculture and represents a promising substitute for chemical fertilizers (Puri et al., 2018). Results of the Table 3 showed that all the 24 endophytic bacterial isolates tested for ammonia production gave positive reaction The isolate EBT22 recorded very high (++++) ammonia production and $45.8 \%$ of the total isolates showed highest $(+++)$ production of ammonia. The least production of ammonia was shown only by four isolates (EBT5, EBT11, EBT24 and EBT25) (Fig. 1).

\section{HCN production}

$\mathrm{HCN}$ is produced by many rhizobacteria and is known to play a major role in biocontrol of pathogens (Defago et al., 1990). The ability of 24 endophytic bacterial isolates to produce $\mathrm{HCN}$ was determined by picric acid assay. Among the 24 isolates, eight isolates(EBT1, EBT2, EBT8, EBT11, EBT15, EBT16, EBT21 and EBT23) have shown highest (+++) production of $\mathrm{HCN}$ while Seven isolates (EBT4, EBT6, EBT7, EBT9, EBT14, EBT18 and EBT22) have shown least (+) production of $\mathrm{HCN}$. Moderate $(++)$ production of $\mathrm{HCN}$ was recorded by four isolates (EBT3, EBT13, EBT24 and EBT25) and only five isolates (EBT5, EBT10, EBT17, EBT19, EBT20) have not shown (-) HCN production (Table 3). Six endophytic bacteria isolated from corn roots were identified as Bacillus sp. and Enterobacter sp. by $16 \mathrm{~S}$ rRNA gene sequencing.

Table.1 List of endophytic bacterial isolates and their source of isolation

\begin{tabular}{|c|c|l|c|}
\hline S.No & $\begin{array}{c}\text { Number of } \\
\text { isolates }\end{array}$ & Isolate Name & Source of Isolation \\
\hline $\mathbf{1}$ & 8 & $\begin{array}{l}\text { EBT1, EBT5, EBT7, EBT 12, EBT15, } \\
\text { EBT19, EBT23, EBT25 }\end{array}$ & Stem \\
\hline $\mathbf{2}$ & 12 & $\begin{array}{l}\text { EBT2, EBT3, EBT6, EBT8, } \\
\text { EBT9,EBT10 EBT13, EBT16. EBT18, } \\
\text { EBT20, EBT21, EBT24 }\end{array}$ & Root \\
\hline $\mathbf{3}$ & $\mathbf{4}$ & EBT4, EBT14, EBT17, EBT22 & Leaf \\
\hline
\end{tabular}


Table.2 Colony characteristics of different isolates of endophytic bacteria

\begin{tabular}{|c|c|c|c|c|c|c|c|}
\hline Isolate & Shape & Pigmentation & Margins & Elevation & Appearance & $\begin{array}{c}\text { Gram staining } \\
\text { reaction }\end{array}$ & $\begin{array}{l}\text { Shape under } \\
\text { microscope }\end{array}$ \\
\hline EBT 1 & Circular & White & Entire & Raised & Shiny & Gram Positive & $\operatorname{Rod}$ \\
\hline EBT 2 & Irregular & White & Undulate & Raised & Dull & Gram Positive & Rod \\
\hline EBT 3 & Irregular & White & Undulate & Flat & Dull & Gram Positive & Rod \\
\hline EBT 4 & Circular & White & Undulate & Flat & Dull & Gram Positive & Rod \\
\hline EBT 5 & Irregular & White & Undulate & Flat & Shiny & Gram Positive & Rod \\
\hline EBT 6 & Irregular & White & Undulate & Flat & Dull & Gram Positive & Rod \\
\hline EBT 7 & Irregular & White & Undulate & Flat & Shiny & Gram negative & Rod \\
\hline EBT 8 & Circular & White & Entire & Flat & Dull & Gram positive & Rod \\
\hline EBT 9 & Wrinkled & White & Undulate & Flat & Dull & Gram Positive & Rod \\
\hline EBT 10 & Irregular & White & Undulate & Raised & Shiny & Gram Positive & Rod \\
\hline EBT 11 & Circular & White & Undulate & Flat & Dull & Gram Positive & Rod \\
\hline EBT 13 & Circular & White & Entire & Raised & Dull & Gram Positive & Rod \\
\hline EBT 14 & Circular & White & Undulate & Flat & Dull & Gram Positive & Rod \\
\hline EBT 15 & Circular & White & Entire & Flat & Shiny & Gram Positive & Cocci \\
\hline EBT 16 & Circular & White & Entire & Raised & Shiny & Gram negative & Rod \\
\hline EBT 17 & Circular & Cream & Entire & Raised & Shiny & Gram negative & Cocci \\
\hline EBT 18 & Irregular & Cream & Entire & Flat & Shiny & Gram positive & Rod \\
\hline EBT 19 & Irregular & White & Undulate & Flat & Dull & Gram Positive & Cocci \\
\hline EBT 20 & Circular & White & Entire & Flat & Shiny & Gram Positive & Cocci \\
\hline EBT 21 & Wrinkled & Yellow & Undulate & Raised & Shiny & Gram Positive & Cocci \\
\hline EBT 22 & Irregular & White & Entire & Flat & Dull & Gram Positive & Rod \\
\hline EBT23 & Irregular & $\begin{array}{l}\text { Creamy } \\
\text { yellow }\end{array}$ & Undulate & Flat & Shiny & Gram Positive & Rod \\
\hline EBT 24 & Circular & White & Entire & Flat & Shiny & Gram negative & Rod \\
\hline EBT 25 & Circular & White & Entire & Raised & Shiny & Gram Positive & Cocci \\
\hline
\end{tabular}


Fig.1 Screening of endophytic bacterial isolates for (a) ammonia production (b) HCN production- a) Weak production of ammonia ; b) Moderate production of ammonia; c) Strong production of ammonia; d)Very strong production of ammonia

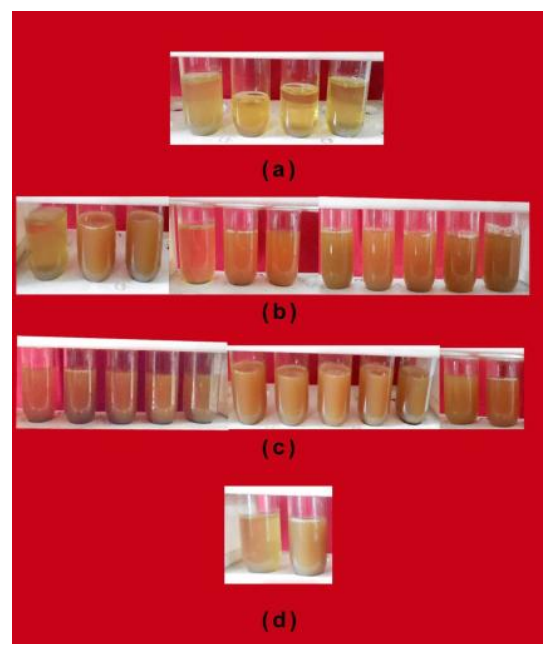

(a)

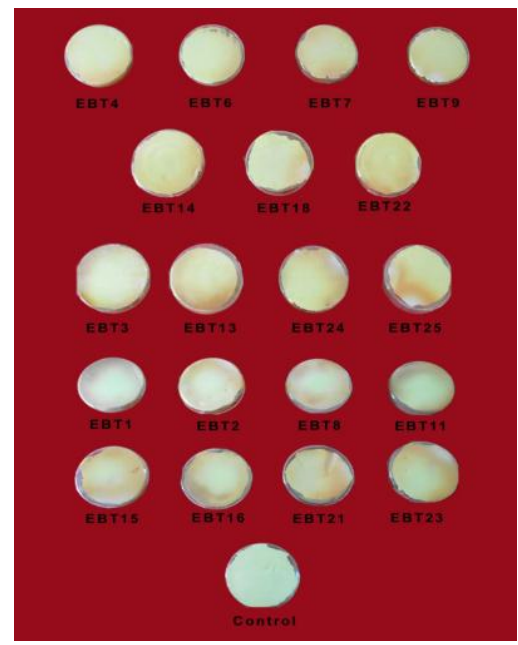

(b)

Table.3 Biochemical tests for characterization of endophytic bacterial isolates

\begin{tabular}{|c|c|c|c|c|}
\hline Isolate & $\begin{array}{l}\text { IAA } \\
\text { production }\end{array}$ & $\begin{array}{c}\text { Ammonia } \\
\text { production }\end{array}$ & $\begin{array}{c}\text { HCN } \\
\text { production }\end{array}$ & Siderophore production \\
\hline EBT 1 & + & +++ & +++ & ++ \\
\hline EBT 2 & - & ++ & +++ & - \\
\hline EBT 3 & + & ++ & ++ & - \\
\hline EBT 4 & - & ++ & + & - \\
\hline EBT 5 & - & + & - & - \\
\hline EBT 6 & - & +++ & + & - \\
\hline EBT 7 & - & +++ & + & - \\
\hline EBT 8 & ++ & ++ & +++ & + \\
\hline EBT 9 & ++ & +++ & + & - \\
\hline EBT 10 & ++ & +++ & - & + \\
\hline EBT 11 & +++ & + & +++ & + \\
\hline EBT 13 & +++ & ++ & ++ & - \\
\hline EBT 14 & +++ & +++ & + & + \\
\hline EBT 15 & +++ & ++ & +++ & - \\
\hline EBT 16 & +++ & ++ & +++ & - \\
\hline EBT 17 & + & +++ & - & - \\
\hline EBT 18 & +++ & ++ & + & ++ \\
\hline EBT 19 & ++ & +++ & - & - \\
\hline EBT 20 & ++ & +++ & - & ++ \\
\hline EBT 21 & - & +++ & +++ & - \\
\hline EBT 22 & + & ++++ & + & - \\
\hline EBT 23 & + & +++ & +++ & - \\
\hline EBT 24 & + & + & ++ & - \\
\hline EBT 25 & - & + & ++ & - \\
\hline
\end{tabular}


Table.4 Quantitative estimation of IAA produced by isolates of endophytic bacteria

\begin{tabular}{|c|c|c|c|}
\hline $\begin{array}{c}\text { S.N } \\
\mathbf{0 .}\end{array}$ & Isolate ID & $\begin{array}{c}\text { IAA production } \\
\text { withtryptophan } \\
\boldsymbol{\mu g g} / \mathbf{m l}\end{array}$ & $\begin{array}{c}\text { IAA production without } \\
\text { tryptophan } \\
\boldsymbol{\mu} \text { /ml }\end{array}$ \\
\hline $\mathbf{1}$ & EBT1 & $23.1 \pm 0.30$ & $\mathbf{1 9 . 8} \pm \mathbf{0 . 4 5}$ \\
\hline $\mathbf{2}$ & EBT3 & $25.2 \pm 0.40$ & $\mathbf{1 4 . 5} \pm \mathbf{0 . 4 0}$ \\
\hline $\mathbf{3}$ & EBT8 & $29.6 \pm 0.35$ & $\mathbf{2 1 . 5} \pm \mathbf{0 . 3 0}$ \\
\hline $\mathbf{4}$ & EBT9 & $25.7 \pm 0.35$ & $\mathbf{1 6 . 1} \pm \mathbf{0 . 3 5}$ \\
\hline $\mathbf{5}$ & EBT10 & $27.7 \pm 0.45$ & $\mathbf{1 7 . 8} \pm \mathbf{0 . 2 5}$ \\
\hline $\mathbf{6}$ & EBT11 & $29.5 \pm 0.20$ & $\mathbf{1 9 . 7} \pm \mathbf{0 . 3 2}$ \\
\hline $\mathbf{7}$ & EBT13 & $28.6 \pm 0.15$ & $\mathbf{2 1 . 7 0} \pm \mathbf{0 . 3 5}$ \\
\hline $\mathbf{8}$ & EBT14 & $30.7 \pm 0.41$ & $\mathbf{1 6 . 0} \pm \mathbf{0 . 5 0}$ \\
\hline $\mathbf{9}$ & EBT15 & $29.7 \pm 0.20$ & $\mathbf{1 7 . 4} \pm \mathbf{0 . 4 5}$ \\
\hline $\mathbf{1 0}$ & EBT16 & $27.5 \pm 0.35$ & $\mathbf{1 8 . 8 8} \pm \mathbf{0 . 3 6}$ \\
\hline $\mathbf{1 1}$ & EBT17 & $20.2 \pm 0.30$ & $\mathbf{1 1 . 3} \pm \mathbf{0 . 2 5}$ \\
\hline $\mathbf{1 2}$ & EBT18 & $40.2 \pm 0.10$ & $\mathbf{1 9 . 2} \pm \mathbf{0 . 1 0}$ \\
\hline $\mathbf{1 3}$ & EBT19 & $23.6 \pm 0.25$ & $\mathbf{2 1 . 7 3} \pm \mathbf{0 . 3 1}$ \\
\hline $\mathbf{1 4}$ & EBT20 & $23.4 \pm 0.26$ & $\mathbf{1 9 . 6 4} \pm \mathbf{0 . 2 3}$ \\
\hline $\mathbf{1 5}$ & EBT22 & $27.9 \pm 0.55$ & $\mathbf{1 3 . 4} \pm \mathbf{0 . 3 0}$ \\
\hline $\mathbf{1 6}$ & EBT23 & $16.4 \pm 0.25$ & $\mathbf{1 5 . 3} \pm \mathbf{0 . 2 0}$ \\
\hline $\mathbf{1 7}$ & EBT24 & $\mathbf{1 6 . 6 7} \pm \mathbf{0 . 0 2}$ & $\mathbf{1 2 . 5} \pm \mathbf{0 . 1 5}$ \\
\hline & & & \\
\hline
\end{tabular}

Fig.2 Screening of endophytic bacterial isolates for siderophore production

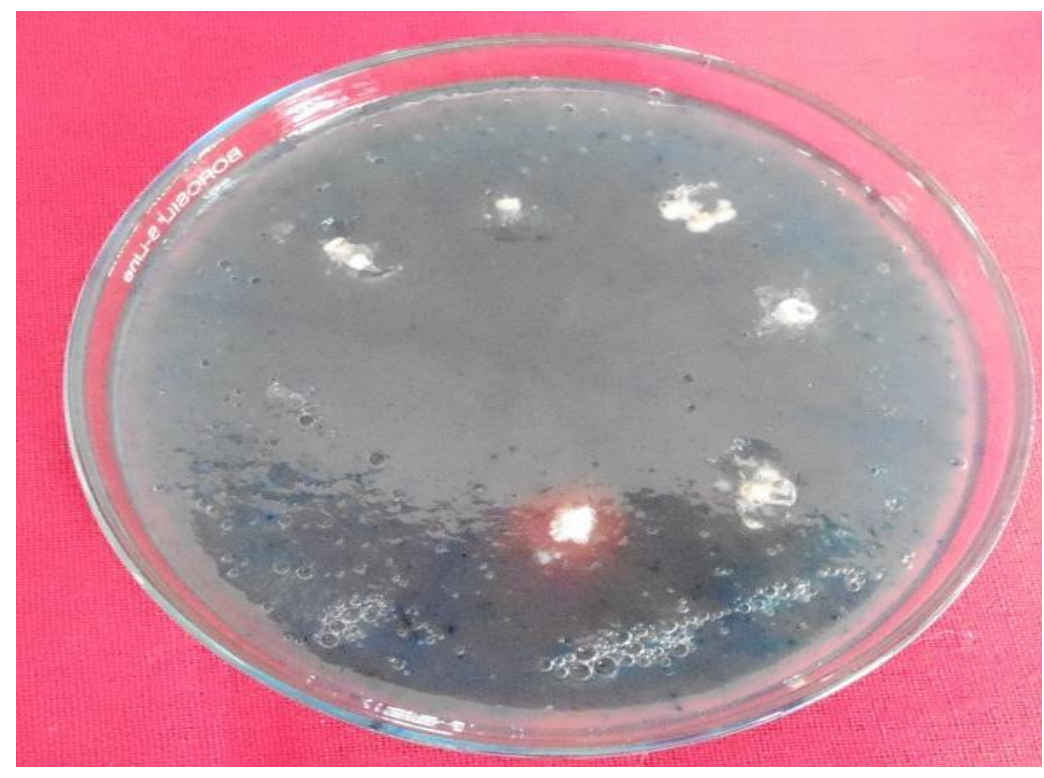


Table.5 Phylogenetic identity of 16S rRNA gene sequences after BLAST analysis

\begin{tabular}{|c|c|l|l|l|}
\hline Isolate Name & $\begin{array}{l}\text { Similarity } \\
\text { percentage }\end{array}$ & Closest Gen Bank match & $\begin{array}{l}\text { Strain } \\
\text { identified }\end{array}$ & Accession No. \\
\hline EBT8 & $99.27 \%$ & $\begin{array}{l}\text { Bacillus xiamenensis strain } \\
\text { MCCC 1A00008 16S ribosomal } \\
\text { RNA, partial sequence }\end{array}$ & $\begin{array}{l}\text { Batlus } \\
\text { xiamenensis }\end{array}$ & MK81100 \\
\hline EBT14 & $99.07 \%$ & $\begin{array}{l}\text { Bacillus aerius strain 24K 16S } \\
\text { ribosomal RNA, partial sequence }\end{array}$ & Bacillus aerius & MK881084 \\
\hline EBT18 & $94.09 \%$ & $\begin{array}{l}\text { Bacillus stratosphericus strain } \\
\text { 41KF2a 16S ribosomal RNA, } \\
\text { partial sequence }\end{array}$ & $\begin{array}{l}\text { Bacillus } \\
\text { stratosphericus }\end{array}$ & MK881075 \\
\hline EBT22 & $99.28 \%$ & $\begin{array}{l}\text { Bacillus safensis strain NBRC } \\
100820 \quad 16 S \text { ribosomal RNA, } \\
\text { partial sequence }\end{array}$ & Bafensis \\
saflus & MK836054 \\
\hline
\end{tabular}

Fig.3 Gel photographs of genomic DNA of isolates of endophytic bacteria [(a) EBT8; (b) EBT 14; (c) EBT 18; (d) EBT 22)
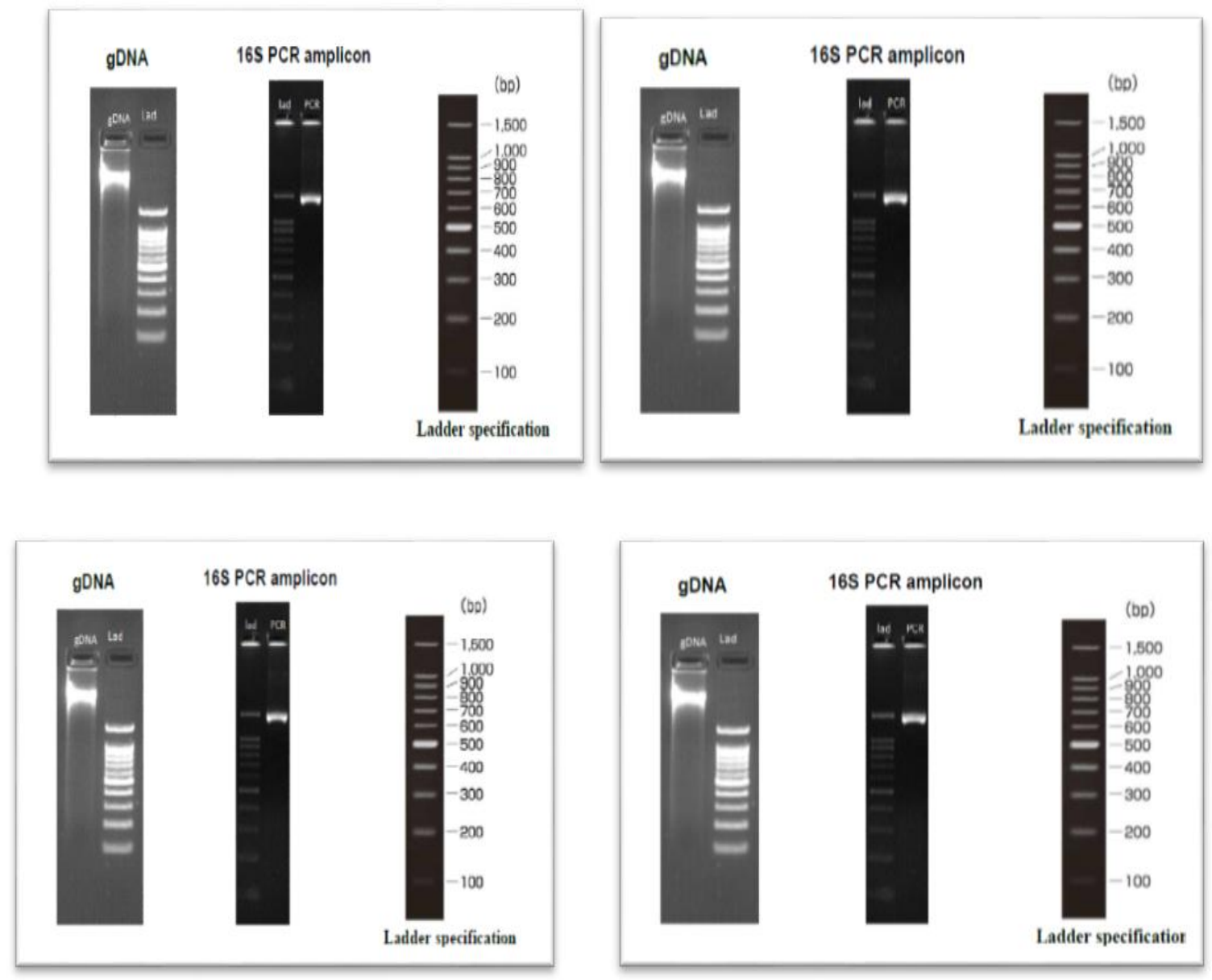
Four of these isolates were found to be positive for nitrogen fixation and the remaining two strains have shown outstanding production of IAA, siderophores and lytic enzymes but none of them have shown positive production of HCN (Szilagyi et al., 2014). However, in the present study, except five isolates all the other isolates were positive for $\mathrm{HCN}$ production

\section{Siderophore production}

The siderophore production was found to become of the mechanisms to outcompete the pathogens (O'Sullivan et al., 1992; Schippers et al., 1987). Production of antimicrobial compounds is directly induced by siderophore producing ability of bacteria (Joseph et al., 2012).Out of the 24 isolates tested for siderophore production, seven isolates have shown positive response which includes EBT1, EBT8, EBT10, EBT11, EBT14, EBT18 and EBT20 with highest production by the isolate EBT20 (Table 3). All other isolates were found to be negative for production of siderophore. Siderophore production by endophytic microorganisms facilitates in colonization of bacteria to the host tissue from rhizospheric zone (Loaces et al., 2011) (Fig. 2).

\section{IAA production}

All the 24 isolates were tested for IAA production and 17 isolates exhibited significant amount of IAA production after 24 hours of incubation with tryptophan. The data (Table 3) indicated that seventeen (17) isolates of endophytic bacteria from the plant were able to produce IAA, the primary auxin in plant growth promotion by utilization of tryptophan. Several bacteria with the ability to anabolize IAA with the supplementation of Ltryptophan have been isolated from the plant surface (Patel et al., 2012)]. Bacterial IAA enhances the development of root system and thus resulting in high water and nutrient uptake (Patten et al., 1996). Bacterial IAA producers (BIPs) have the potential to interfere with any of plant's physiological processes by input of IAA into the plant's auxin pool (Johan et al., 2005).

\section{Quantitative production of indole acetic acid}

The quantity of IAA produced was determined by measuring the OD values at $530 \mathrm{~nm}$. Among all the twenty four isolates tested, IAA production varied with and without tryptophan supplementation and results are presented in the (Table 4). In the presence of tryptophan, the highest IAA production was shown by theisolateEBT18 $(40.2 \mu \mathrm{g} / \mathrm{ml})$ followed by the isolate EBT $14(30.7 \mu \mathrm{g} / \mathrm{ml})$. The least production of IAA was recorded by the isolate EBT23 $(16.4 \mu \mathrm{g} / \mathrm{ml})$ followed by EBT24 @ $16.67 \mu \mathrm{g} / \mathrm{ml}$ in the presence of tryptophan. In the absence of tryptophan, the highest production of IAA was recorded by the isolates EBT19 and EBT13 that are on par with each other with respective values of $21.73 \mu \mathrm{g} / \mathrm{ml}$ and $21.70 \mu \mathrm{g} / \mathrm{ml}$ whereas the least production of IAA was observed in the isolate EBT17 followed by the isolate EBT24 that have shown IAA production of $11.3 \mu \mathrm{g} / \mathrm{ml}$ and 12.5 $\mu \mathrm{g} / \mathrm{ml}$ respectively. Many bacteria have the ability to synthesize IAA either in the presence or absence of tryptophan but the microbes produce larger quantities of IAA in the presence of tryptophan (Normanly, 1997; Venis et al., 1991).

\section{Molecular characterization of endophytic bacteria}

The four isolates which were found to be effective in plant growth promotion and per cent disease reduction under glass house conditions were characterized and identified based on 16S rRNA gene sequencing (Figure $3)$. 
The 16S rRNA gene sequence of the isolates were compared with other bacterial sequence by BLAST (http://www.ncbi.nlm.nih.gov/ Blast/Blast.cgi). The result was compared with the sequence of GenBank based on partial $16 \mathrm{~S}$ rRNA to check the relationship and similarity with the endophytic isolates. The results showed similarity of EBT 8 at 99.27 per cent with Bacillus xiamenensis, similarity of EBT 14 at 99.07 per cent with Bacillus aerius, similarity of EBT18 with Bacillus stratosphericus at 94.09 per cent and similarity of EBT 22 at 99.28 per cent with Bacillus safensis. The details of the sequence data of all the five potential isolates are presented in the Table 5.

This research concluded that the endophytic bacteria from Lycopersicon esculentum Mill produced one or more different characteristics that have better potential than generally used commercial fungicides. They produced phytohormones like IAA, ammonia, $\mathrm{HCN}$ and siderophore, which are beneficial in plant growth promotion and disease management. The potential isolates of endophytic bacteria were further characterized at molecular level by $16 \mathrm{~S}$ rRNA gene sequencing for identification. Based on the sequencing, the potential endophytic isolates were identified as Bacillus sp.

\section{Acknowledgments}

The authors acknowledge the financial help rendered by the Professor Jayashankar Telangana State Agricultural University (PJTSAU), Rajendranagar, Hyderabad.

\section{References}

Amaresan, N., Jayakumar, V., Krishna Kumar, and Thajuddin, $\mathrm{N}$ 2012. Isolation and characterization of plant growth promoting endophytic bacteria and their effect on tomato (Lycopersicon esculentum) and chilli (Capsicum annum) seedling growth. Annals of microbiology. 62: 805-810.

Backman, P. A and Sikora, R. A. 2008. Endophytes: An emerging tool for biological control. Biological Control.46 (1): $1-3$

Bakker, A. W and Schippers, B. 1987. Microbial cyanides production in the rhizosphere in relation to potato yield reduction and Pseudomonas spp. mediated plant growth stimulation. Soil Biology and Biochemistry. 19: 451-457.

Cappuccino, J. $\mathrm{C}$ and Sherman, N. 1992.Microbiology: A Laboratory Manual, 3rd edition. Benjamin/ Cummings publishing. Co.:125-179.

Chun, J and Goodfellow, M. 1995. A phylogenetic analysis of the genus Nocardia with 16S rRNA gene sequences. International Journal of Systematic Bacteriology.45:240- 245.

Defago, G., Berling, C. H., Burger, U., Haas, D., Kahr, G., Keel, C., Voisard, C., Wirthner, P and Wuthrich, B. 1990. Suppression of black root rot of tobacco and other root diseases by strains of Pseudomonas fluorescens potential applications and mechanisms. (eds.In: Hornby D.) Biological control of soil borne plant pathogens. CAB International, Walligfort, Oxon, U.K, 9398pp.

Feng, H., Li, Y and Liu, Q. 2013. Endophytic bacterial communities in tomato plants with differential resistance to Ralstonia solanacearum. African Journal of Microbiology Research. 7 (15): 1311-1318.

Glickmann, E., Dessaux, Y. 1995. A critical examination of the specificity of the salkowski reagent for indolic compounds produced by phytopathogenic bacteria. Applied and Environmental Microbiology. 61(2): 793-796.

Hallman, J., Quadt-Hallman, A., Mahafee, W. F and Kloepper, J. W. 1997. Bacterial endophytes in agricultural crops. Canadian Journal of Microbiology. 43(10):895-914.

Inuwa $\mathrm{AB}$, Maryam YA, Arzai $\mathrm{AH}$, Hafsat $\mathrm{YB}$, Kawo AH, Usman AU, Ama $\mathrm{S} J$ and Ibrahim K H 2017. Distribution of cultural endophytic bacteria in lemon grass (Cymbopogan citratus). Bayero Journal of 
Pure and Applied Sciences. 10(1): 95-98.

INDIASTAT. 2017-2018. http://www.indiastat. com/agriculture/2/stats.aspx.

Johan H J Leveau and Steven E Lindow 2005. Utilization of plant hormone Indole-3Acetic acid for growth by Psedomonas putida strain 1290. Applied and Environmental Microbiology. 71(15):23652371.

Joseph B, Patra RR, Lawrence R 2012. Characterization of plant growth promoting rhizobacteria associated with chickpea (Cicer arietinum L.). International Journal of Plant Production. 2:141-1520.

Loaces I, Lucía F and Ana, F S 2011. Dynamics, diversity and function of endophytic siderophore- producing bacteria in rice. Microbial Ecology. 61:606-618.

Normanly, J 1997. Auxin metabolism. Physiologia Plantarum. 100: 431 -442.

O'Sullivan D J and O'Gara F 1992. Traits of fluorescent Pseudomonas spp. involved in suppression of plant root pathogens. Microbiological Reviews. 56: 662-676.

Padder SA, Dar GH, Bhat Z A, Verma K and Wani A B 2017. Morphological, metabolic and biochemical characterization of bacterial root endophytes associated with brown sarson (Brassica rapa L.). Journal of Pharmacognosy and Phytochemistry. 6 (2): 226-232.

Patten CL, Glick B R 1996. Bacterial biosynthesis of Idole-3-acetic acid. Canadian Journal of Microbiology.42 (3):207-220.

Patel HA, Patel RK, Khristi S M, Parikh K and Rajendran G 2012. Isolation and characterization of bacterial endophytes from Lycopersion esculentum plant and their plant growth promoting characteristics. Nepal Journal of Microbiology. 2(1): 37-52.

Puri A, Padda K P and Chanway C P 2018. Nitrogen-Fixation by Endophytic Bacteria in Agricultural Crops: Recent Advances. In Nitrogen in Agriculture - Updates. InTech.

Rosenblueth M and Romero E 2006. Bacterial endophytes and their interactions with hosts. Molecular Plant-Microbe Interactions. 19 (8): 827-837.

Ryan RP, Germaine K, Franks A, Ryan D J and Dowling D N 2008. Bacterial endophytes: Recent developments and applications. FEMS Microbiology Letters. 278 (1): 1-9.

Saxer G, Doebeli M and Travisano M 2010. The repeatability of adaptive radiation during long term experimental evolution of Escherichia coli in a multiple nutrient environment. PLOS ONE. 5(12):14184.

Schippers B, Bakker A W and Bakker PAH M 1987. Interactions of deleterious and beneficial rhizosphere microorganisms and the effect of cropping practices. Annual Review of Phytopathology. 25:339-358.

Szilagyi-Zecchin, V J, Ikeda A C, Hungria M, Adamoski D, Kava-Corderio V, Glienke C and Galli-Terasawa LV 2014. Identification and characterization of endophytic bacteria from corn (Zea mays L.) roots with biotechnological potential in agriculture. AMB Express. 4(1): 26.

Venis M A and Napier R M 1991. Auxin receptors: recent developments. Plant Growth Regulation.10: 329-340.

\section{How to cite this article:}

Sai Sushma, B., B. Vidya Sagar, S. Triveni and Uma Devi, G. 2020. Isolation, Biochemical and Molecular Characterization of Endophytic Bacteria from Tomato (Lycopersicon esculentum Mill.). Int.J.Curr.Microbiol.App.Sci. 9(11): 2261-2271.

doi: https://doi.org/10.20546/ijcmas.2020.911.271 